\title{
\#1
}

\section{Meniti Idealisme Wartawan: Kegamangan yang Tak Pernah Selesai}

\author{
Ana Nadhya Abrar
}

Kegamangan seorang wartawan atau jurnalistik tentunya tidak akan membunuh kreativitasnya. Bahkan dalam sistem yang sudah mapan pun, seorang wartawan tetap perlu memiliki kehati-hatian penggamang. Cuma bedanya, kehati-hatian ini akan menjadi sikap dalam menempatkan kehadirannya di tengah masyarakat. Kita ingatkan, kegiatan jurnalistik mengandung kualitas yang bersifat intelektualitas. Karena pelaku profesi ini akan memelihara wawasan yang terkait dengan perjalanan peradaban.

Demikian Ashadi Siregar (1985:9) menyuarakan pendapatnya tentang pentingnya mempertahankan kegamangan wartawan dalam buku berjudul Profesi Wartawan di Mata Saya. Dalam pendapat itu, setidaknya terdapat dua hal yang perlu digaris bawahi. Pertama, kegiatan wartawan membawa misi intelektualitas. la 
harus meningkatkan intelektualitas khalayak yang membaca beritanya. Kedua, wartawan harus berhati-hati dalam meningkatkan intelektualitas khalayaknya. Begitu hati-hatinya, sehingga dia khawatir tidak bisa menjalankan tugasnya dengan baik.

Kedua pesan itu disampaikan Ashadi Siregar ketika otoritarianisme orde baru makin merebak. Ketika itu kebebasan pers tetap ada. Namun, disertai dengan kondisi yang bertanggung jawab. Seperti apa persisnya kebebasan pers itu, hanya pemerintah yang tahu. $\mathrm{Ya}$, pemerintah yang menentukan kebebasan pers yang harus dipraktikkan dan pemerintah pula yang menentukan kapan sebuah media pers melanggar kebebasan pers.

Setelah Undang-Undang No. 40 Tahun 1999 tentang Pers berlaku, media pers memiliki kebebasan pers yang riil. Media pers keluar dari kekhawatiran akan dibredel pemerintah. Namun, apakah wartawan sudah bebas menulis berita yang meningkatkan intelektualitas khalayak? Apakah wartawan tidak perlu gamang lagi meniti idealismenya? Uraian berikut akan mendiskusikan jawabannya.

\section{Idealisme Wartawan}

Idealisme wartawan dibutuhkan untuk meyakinkan wartawan tentang tanggung jawab profesinya. Hal tersebut merupakan garis yang membatasi perilaku terpuji dan tidak terpuji wartawan. Idealisme menentukan kualitas wartawan. Begitulah, idealisme merupakan obsesi yang harus dikejar dan kerinduan yang harus dipuaskan secara etis.

Namun, sebuah pertanyaan tiba-tiba menyergap, apakah sebenarnya idealisme wartawan itu? Sebelum menjawab pertanyaan ini, marilah kita berimajinasi tentang kisah seorang reporter televisi kabel di Amerika Serikat bernama Andy Malone yang ingin mewawancarai seorang pensiunan Jenderal perang 
bernama Michael Ratliff. Kisah itu diabadikan oleh Sandra Brown dalam novelnya yang berjudul Prime Time. Dalam kisah itu digambarkan Andy berusaha betul mencari kesempatan untuk mewawancarai Michael Ratliff. Usahanya dihalang-halangi oleh anak Ratfliff yang bernama Lyon Ratliff.

Andy tidak pernah surut. Dia melakukan semua cara yang dibenarkan akal sehat. Berkat yakin dan kerja keras akhirnya dia bisa bertemu dengan Michael Ratliff. Dalam perjumpaan pertama dengan Andy, Michael bertanya tentang alasan Andy ngotot mewawancarainya. Andy menjawab,

"Jenderal Ratliff, tentu Anda sudah menebak alasannya. Anda adalah bagian dari sejarah Amerika. Nama Anda akan selalu tercantum dalam setiap buku teks yang membahas Perang Dunia II. Selama bertahun-tahun Anda mengasingkan di ranch ini. Publik Amerika penasaran, ingin tahu alasannya. Mereka ingin mengetahui kegiatan Anda." (Brown, 2017:40)

Menyimak kutipan di atas, tentu kita berpendapat Andy Malone berusaha keras mewawancarai Michael Ratliff demi memenuhi rasa ingin tahu khalayak. Dengan segala cara dia berusaha melayani hak mengetahui khalayak. Wajar bila berhasil menyingkap apa yang dilakukan Ratliff setelah pensiun kepada khalayak menjadi obsesi Andy.

Beriringan dengan melayani hak mengetahui, ada melayani hak menyatakan pendapat khalayak. Keduanya bergerak secara bersama. Ketika berniat melayani hak mengetahui khalayak, Andy sesungguhnya menyadari ada hak lain khalayak lain yang harus dia layani juga, hak menyatakan pendapat. Sangat tidak fair kalau Andi hanya fokus pada melayani hak mengetahui khalayak saja.

Tidak diperoleh informasi tentang apa yang terjadi pada Andy setelah berhasil menayangkan hasil wawancaranya dengan 
Michael Ratliff di televisi kabel tempat dia bekerja. Namun, tentu kita bisa membayangkan sambutan hangat redakturnya. Bukan mustahil Andy memperoleh promosi ke jabatan yang lebih tinggi.

Sampai di sini tentu muncul pertanyaan, apakah Andy Malone sengaja melakukan wawancara eksklusif dengan Michael Ratliff demi mendapat promosi jabatan? Katakanlah Andy Malone memang punya motif untuk memperoleh promosi usai menyiarkan hasil wawancaranya dengan Michael Ratliff. Namun, promosi itu terjadi setelah dia berhasil melayani hak mengetahui khalayak. Tanpa melayani hak mengetahui khalayak, dia tidak akan memperoleh promosi jabatan.

Bagi Andy Malone, melayani hak mengetahui khalayak merupakan kewajibannya. Melayani hak mengetahui khalayak bagi Andy Malone, bukan sekadar anak tangga memperoleh promosi jabatan. la menjadi bagian terpenting dalam pekerjaannya sebagai seorang reporter. la bahkan menjadikan pelayanan itu sebagai misi yang harus dilakukannya. Bersamaan dengan itu, dia juga menjadikan melayani hak menyatakan pendapat khalayak sebagai misi yang harus dia jalani juga.

Kalau sudah menjadi misi, tentu timbul pertanyaan, apa visinya? Pertanyaan ini masuk akal. Bukankah misi dijalankan untuk mencapai visi? Untuk membayangkan visi wartawan, marilah kita berimajinasi tentang hasil wawancara Andy Malone dengan Michael Ratliff yang disiarkan televisi kabel tempatnya bekerja.

Memang hasilnya hanya informasi. Namun, informasi itu mengandung gagasan. Gagasan itu bisa membangkitkan kesadaran khalayak tentang kepahlawanan, nasionalisme dan sebagainya. Ini bisa membuka pikiran khalayak untuk mendiskusikan makna kepahlawanan dan nasionalisme tersebut.

Kecuali itu, khalayak juga bisa memikirkan makna kepahlawanan dan nasionalisme itu serta mencari kaitan antara masa lalu dan 
masa sekarang. Mereka juga bisa mempertaruhkan gagasannya. Mereka bahkan bisa mengajukan gagasannya untuk menjadi perbandingan bagi orang lain memformulasikan gagasannya.

Tidak mudah memang membayangkan apa yang sesungguhnya terjadi pada khalayak televisi kabel tempat Andy bekerja pasca menonton hasil wawancara Andy dengan Ratliff. Namun, mengikuti imajinasi di atas, sesungguhnya informasi tersebut sudah meningkatkan intelektualitas khalayak. Nah, meningkatkan intelektualitas khalayak inilah sesungguhnya yang menjadi visi Andy Malone sebagai wartawan. Visi inilah yang bisa diklaim sebagai idealismenya.

Walaupun kisah Andy Malone di atas terdokumentasi dalam sebuah novel, peristiwa yang terungkap tidak bisa disebut sebagai khayalan semata. la mendidik kita tentang bagaimana seorang wartawan harus mempraktikkan idealismenya. Idealisme itu, kalau ingin diungkap dalam sebuah frasa, menjadi: meningkatkan intelektualitas khalayak. Tegasnya, yang menjadi urusan hakiki bagi wartawan dalam relasinya dengan khalayak adalah meningkatkan intelektualitasnya.

Agar bisa meningkatkan intelektualitas khalayak melalui berita, tentu saja seorang wartawan harus mematuhi segala batas pemberitaan. Batas pemberitaan itu, antara lain UU No. 40 Tahun 1999 tentang Pers, Kode Etik Jurnalistik, UU KUHP dan Kode Perusahaan Media. Namun, batasan pemberitaan ini tidak bisa disebut sebagai idealisme wartawan. la merupakan kaidah moral profesi wartawan. Pelanggaran terhadap semua kaidah itu akan menuai sanksi. Sanksinya beragam, mulai dari sanksi moral, sanksi organisasi profesi wartawan, sanksi manajemen hingga sanksi hukum. 


\section{Bergantung pada Framing Berita}

Kesadaran akan peningkatan intelektualitas khalayak dilakukan wartawan melalui teks dan gambar. Teks dan gambar memiliki bahasanya sendiri. Bahasa teks dan bahasa gambar juga punya logika tersendiri. Namun, keduanya merupakan alat interaksi antara wartawan dan khalayaknya.

Ketika seorang wartawan sudah menentukan bahasa yang akan digunakannya dalam menulis berita, sesungguhnya dia melakukannya dengan sadar. Dia mengerti persis, bahasa itu menjadi alat dedikasinya pada pekerjaan. Meminjam pendapat Heidegger yang terdokumentasi dalam buku Filsafat Manusia: Jendela Menyingkap Humanisme karya Kasdin Sihotang (Sihotang, 2018:163) bahasa itu bukan lahir dari perbuatan semata, tetapi juga gerakan eksistensial untuk menunjukkan keterlibatan wartawan. Wartawan juga ingin menunjukkan eksistensi dirinya.

Dalam situasi begini, melalui bahasa sebenarnya seorang wartawan mengungkapkan dirinya kepada khalayak. Apa yang diungkapkannya? Tentu saja apa yang ada dalam pikirannya kepada khalayak. Namun, kita mengerti, wartawan tidak bisa langsung mempraktikkan ide ini kepada khalayak. Soalnya, ia bisa meluncur jadi opini. Padahal semua orang mengerti, wartawan tidak boleh beropini dalam berita yang ditulisnya!

Lalu apa yang harus dilakukan wartawan? Agaknya mereka bisa melakukannya melalui framing berita. Ya, wartawan bisa menempuh framing berita untuk mengungkap dirinya kepada khalayak. Soalnya, mem-framing berita merupakan pekerjaan yang sah dalam penulisan berita. Mem-framing berita selalu bertolak dari fakta yang ada.

Dalam keadaan begini, tentu kita butuh pedoman tentang framing berita. Apa pedomannya? Pedoman itu diungkapkan secara 
gamblang oleh Ashadi Siregar dalam buku Politik Editorial Media Indonesia: Analisis Tajuk Rencana 1998-2001 sebagai berikut:

Framing memilik dua sisi tujuan, pertama bersifat internal yaitu sebagai perangkat dalam mengorganisasikan bahan yang diperoleh dari fakta agar dapat direkonstruksikan sebagai teks terstruktur. Kedua, framing merupakan cara untuk menghadirkan makna impilisit (tersirat). Pameo "read between the lines", yaitu makna (meaning) dari suatu teks bukan hanya ditangkap melalui pengertian dari yang tersurat, tetapi juga dari sebalik (beyond) suatu teks. Intensi dan tujuan untuk menyampaikan makna di sebalik teks ini sering berkonteks pada kepentingan publik, atau nilai (value) dan cita-cita sosial yang dipandang luhur yang dirumuskan sebagai visi dan misi media pers (Siregar, 2003).

Hasil kegiatan framing adalah wacana. Wacana merupakan makna yang tersirat dari berita yang ditulis wartawan. la bisa dianggap sebagai ungkapan wartawan yang harus ditangkap oleh khalayak. Dari tangkapan ini, khalayak bisa membuat antitesis dan merumuskan sintesisnya. Kalau khalayak berhasil membuat sintesis wacana dan merumuskan sinstesisnya, sesungguhnya mereka sudah menempuh proses peningkatan intelektualitas.

Sampai di sini tentu muncul pertanyaan, apakah khalayak bisa menangkap wacana yang disampaikan wartawan secara akurat? Memang tidak mudah bagi khalayak menangkap wacana berita secara akurat. Namun, mari kita lihat proses penangkapan wacana itu dengan saksama.

Framing berita terdiri atas dua jenis, yakni framing media dan framing individu. Framing media dilakukan oleh wartawan dan framing individu dilakukan oleh khalayak. Mengenai yang terakhir ini, framing dioperasionalisasikan khalayak di atas basis konstruksi 
sosial. Tentang hal ini, Ana Nadhya Abrar menulis dalam buku Penulisan Berita, edisi kedua, sebagai berikut:

"la akan menjadi dasar bagi khalayak untuk melakukan interpretasi selektif dari wacana yang disampaikan berita. Bagi khalayak, framing individu sama saja dengan pengalaman pribadi dan interaksi dengan kawan sebaya (Neuman et.al, 1992, p. 120). Itulah sebabnya framing individu merupakan kondisi mental dan cetusan ide yang membimbing individu memproses informasi. Dari framing individu inilah khalayak menangkap wacana yang disampaikan wartawan." (Abrar, 2005:37)

Di titik ini, kita berpendapat, peningkatan intelektualitas khalayak ditentukan oleh wacana yang terkandung dalam berita yang ditulis wartawan. Kalau wacana itu memang ada, khalayak akan berusaha menangkapnya dengan framing individu. Kalau wacana itu tidak ada, tentu khalayak tidak bisa melakukan antitesis dan sintesis dari wacana itu. Mereka hanya akan menikmati berita yang tersurat.

Maka wartawan perlu mem-framing berita agar bisa meningkatkan intelektualitas khalayak. Tegasnya, peningkatan intelektualitas khalayak bergantung kepada framing berita.

\section{Memasuki Orde Reformasi}

Tidak lama setelah orde reformasi berjalan, terjadilah liberalisasi media di Indonesia. Media asing boleh mencari uang di medan bisnis Indonesia. Media dalam negeri mulai melakukan ekspansi kapital. Akibatnya, demi kepentingan modal, media Indonesia sedikit demi sedikit mulai kehilangan perannya sebagai watchdog.

Mungkin penggagas Undang-Undang No. 40 Tahun 1999 tentang Pers tidak membayangkan kejadian ini. Seorang penulis barat, bernama Robert W.McChesney menulis di dalam buku berjudul Rich Media, Poor Democracy: Communication Politics in Dubious Times, 
....the contradiction between a for profit, highly concentrated, advertising-saturated, corporate media system and communication requirements of a democratic society (.....kontradiksi antara sistem media korporat yang mencari keuntungan, sangat terkonsentrasi, padat iklan, dan kebutuhan komunikasi masyarakat demokratis) (McChesney, 2000:ix).

Perhatikan bagaimana McChesney melukiskan demi kepentingan laba, media mereduksi perannya dalam memenuhi kebutuhan informasi khalayak. Memang buku tersebut tidak spesifik menceritakan krisis media di Indonesia. Namun, buku itu mengidentifikasi krisis media telah terjadi di Amerika Serikat (dan dunia). Nah, lewat kata "dan dunia" itu, agaknya kita bisa menafsirkannya termasuk di Indonesia.

Sampai di sini tentu timbul pertanyaan, seperti apa sih persisnya kondisi media Indonesia di orde reformasi itu? Jawabannya bisa disimak melalui tulisan R. Kristiawan dalam Majalah Prisma, Volume 30, No. 1, 2011 sebagai berikut:

Dinamika media massa di Indonesia sesudah tahun 1998 tampak lebih menarik ketimbang sebelum 1998, karena pada era itu muncul "dimensi pasar" dengan sangat siginifikan dan mulai menggeser pola analisis klasik otoritarianisme negara. Bagaimana konsentrasi kepemilikan media? Kepemilikan media cetak memang tidaklah segenting masalah kepemilikan media penyiaran. Pada media cetak, tidak ada wilayah publik yang dikuasai swasta, sedangkan swasta pada media penyiaran bisa menguasai domain publik, yakni frekuensi yang merupakan sumber daya terbatas (Kristiawan, 2011:50).

Dalam keadaan begini, wartawan merasa seperti sedang melayang di kebebasan yang mencemaskan. Mereka boleh meningkatkan 
intelektualitas khalayak, namun harus mendatangkan keuntungan maksimal buat medianya. Agaknya, mereka mustahil bisa melakukannya. Soalnya, kenyataan menunjukkan keduanya tidak bisa seiring sejalan. Keduanya malah bertentangan.

Maka wartawan harus memposisikan dirinya di garis pinggiran. Mereka tidak representatif buat media yang ingin menggaet keuntungan materi sebanyak-banyaknya. Mereka dianggap sebagai penghalang cita-cita komersial media pers. Mereka pun merasa gamang meningkatkan intelektualitas khalayak.

Kalau hasil berita wartawan membuat media puas, membuat media memperoleh keuntungan yang banyak, sebenarnya itu wajar saja. Bukankah media itu sudah berinvestasi cukup besar untuk bisa menerbitkan sebuah media? Namun, menjadikan media sematamata alat untuk mencari keuntungan materi tentu tidak elok. Apa bedanya ia lantas dengan perusahaan pembuatan tempe, misalnya?

Seorang wartawan tentu saja tidak bisa memaksakan kehendaknya kepada pemilik media. Kalau dia tetap ngotot, bukan mustahil pemilik media mendepaknya dari media bersangkutan. Kalau seorang wartawan terdepak, ratusan lain siap menggantikannya.

Ini tentu saja tidak sehat bagi wartawan. Wartawan harus berhatihati betul menulis berita yang meningkatkan intelektualitas khalayak. Kita ingat misalnya Luviana ketika tahun 2012, mengkritik newsroom Metro TV. Dia tidak berdaya mempertahankan posisinya sebagai wartawan. Padahal saat itu dia sudah bekerja lebih dari sepuluh tahun. Pemilik Metro TV mementahkan semua argumentasi Luviana yang bertekad meningkatkan intelektualitas khalayak. Akhirnya, Luviana tersingkir dari Metro TV. Kawankawannya di sana diam saja melihat nasib Luviana. Mereka tidak kuasa membela, karena tahu persis kalau ikut-ikutan membela akan mengalami nasib serupa. 
Gambaran tentang perlakuan sewenang-wenang Metro TV terhadap Luviana pernah dilaporkan Kompas.com, 21 Januari 2013 sebagai berikut:

Mantan jurnalis Metro TV, Luviana, mengadukan nasibnya setelah dipecat tanpa alasan jelas oleh manajemen stasiun televisi tersebut ke Komisi IX dan Menteri Tenaga Kerja Muhaimin Iskandar di Gedung Kompleks Parlemen, Senayan, Senin (21/1/2013). Luviana kembali menuntut keadilan dan meminta agar bos Metro TV, Surya Paloh, merealisasikan janjinya. Dalam pertemuan itu, Luviana menceritakan kronologi pemecatannya. la mengatakan, setelah bekerja selama lebih dari 10 tahun, Luviana dibebas tugaskan pada 31 Januari 2012.

"Saat itu, saya mau bekerja pun tidak bisa. Setiap saya datang ke kantor, selalu dihalangi petugas keamanan," ucap Luviana.

Atas sikap tidak menyenangkan itu, Luviana bersama dengan tim litigasi dan nonlitigasi Aliansi Melawan Topeng Restorasi (Metro) dan Aliansi Solidarity for Luviana (Sovi) bertemu dengan Surya Paloh pada tanggal 5 Juni 2012. "Di pertemuan itu, Surya Paloh berjanji akan mempekerjakan kembali di Metro TV," ujar Luviana.

Namun, alih-alih bisa bekerja kembali, Luviana justru menerima surat pemecatan pada 27 Juni 2012. Sejak tanggal 1 Juli 2012 hingga hari ini, Luviana pun tidak mendapatkan gaji (Kompas.com, 21 Januari 2013).

Benar, otoritarianisme orde baru sudah tak ada pada orde era reformasi. Namun, kebebasan pers yang tercipta di orde reformasi telah menciptakan kekuatan baru, yakni kekuasaan pemilik modal yang sangat kuat. Kekuasaan ini, dalam hal memasung wartawan, 
sama saja dengan otoritarianisme orde baru. Sama-sama membuat gamang wartawan mewujudkan idealismenya.

\section{Kekuatan Digitalisasi}

Bagi wartawan memang tidak ada kalah atau menang. Sepanjang bisa meningkatkan intelektualitas khalayak, itu sudah cukup. Namun, bagi pemilik modal dan penguasa, menang itu kewajiban. Keduanya akan berusaha keras untuk menjadi pemenang dari siapa saja yang menantang. Untuk itulah mereka melakukan pengawasan terhadap siapa saja yang dianggap menentang, termasuk meningkatan intelektualitas khalayak.

Revolusi digital menjadikan ada pihak yang bisa menjadi pengawas yang sangat canggih. Megenai ini simaklah pernyataan Agus Sudibyo dalam buku Jagat Digital: Pembebasan dan Penguasaan berikut:

"Pertama, di zaman digitalisasi ini, ada pihak yang sepertinya lebih kuat dan lebih canggih dibandingkan mata-mata atau pengawasan (surveilence). Kedua, institusi pengawasan yang dimaksud bukanlah negara atau institusi formal intelijen, bukan pula lembaga intelijen multilateral, melainkan korporasi swasta (perusahaan penyedia platform atau layanan digital. Ketiga, pengawasan itu dilakukan terutama sekali bukan karena alasan politis atau ideologis, melainkan alasan bisnis atau ekonomi. Keempat, objek pengawasan itu bukan kelompok tertentu, melainkan hampir semua orang. Kelima, kita diawasi bukan karena mengancam atau berbahaya, melainkan justru sebaliknya, dibutuhkan sebagai pemasok data dan objek periklanan untuk korporasi yang dimaksud di atas. Keenam, pengawasan dilakukan tidak dengan peralatan yang sangat eksklusif, mahal, dan jarang, tetapi dengan peralatan yang dimiliki hampir semua orang: telepon genggam." (2019:208) 
Kutipan yang agak panjang ini menunjukkan, tidak ada lagi tempat buat wartawan menjadi otonom. Semua perilaku wartawan sudah diawasi. Mereka tidak bisa leluasa meningkatkan intelektualitas khalayak lewat berita. Kalau berita itu dianggap oleh sebuah korporasi untuk mendatangkan keuntungan, berita tersebut bisa dimanfaatkan. Bukan mustahil malah berita itu kelak menjerat khalayak.

Dalam pada itu, Cahyo Ryan Safrizal menuliskan hasil penelitiannya sebagai berikut:

"tribunjogja.com memiliki tim khusus untuk menunjang kepentingan mereka dalam mencari atensi khalayak (traffic). Tim tersebut bernama tim kreator konten. Tim ini dibuat secara khusus untuk mengusulkan berita yang sesuai dengan selera pembaca." (2021:112)

Keadaan begini membuat wartawan menjadi semakin gelisah bisa mewujudkan idealismenya. Aturan di media online memang lebih terfokus untuk menyiarkan berita yang bisa menjadi trending topic. Sayangnya berita seperti itu tidak memberi tempat untuk meningkatkan intelektualitas khalayak.

Kalau kita bicara dalam ukuran biasa, tentu wartawan akan memilih bekerja demi kepentingan medianya saja. Bukankah mereka memperoleh bayaran dari medianya? Namun, kewajiban utama wartawan tertuju kepada pihak yang memberikan hak menjadi wartawan. Dalam praktik jurnalisme, seperti ditulis Ana Nadhya Abrar (Abrar, 2021:17), yang memberikan hak kepada wartawan menjalankan profesinya adalah khalayak. Namun, hak itu tidak diberikan secara langsung, melainkan melalui media pers tempat wartawan bekerja. Itulah sebabnya muncul pendapat umum yang mengatakan majikan wartawan yang sebenarnya adalah masyarakat yang menerima informasinya. 
Maka, seorang wartawan harus tetap berusaha meningkatkan intelektualitas khalayak semampu yang dia bisa. Kalaupun dia gamang, tentu saja gamang. Namun, seperti yang sudah disebutkan pada awal tulisan, dia harus tetap kreatif. Paling tidak dia harus memiliki kehati-hatian penggamang.

\section{Catatan Akhir}

Dalam situasi atas, semesta dunia wartawan terguncang. Lebih dari itu, wartawan terancam kehilangan arti. Dia tidak bisa otonom. Padahal tanpa otonomi wartawan tidak bisa mempertahankan posisinya sebagai intelektual. Tentang ini Mohamad Sobary menulis:

“....saya menyebut intelektual itu antara lain wartawan, dosen, peneliti, kiai, pastur, biksu, penyair, dramawan, aktivis LSM. Tapi tidak semua orang yang punya profesi seperti itu adalah intelektual. Sebab, tidak sedikit wartawan, peneliti, dosen, dan ruhaniawan yang menjalani hidup secara "aksireaksi", sekadar memenuhi aturan administratif tanpa proses refleksi yang serius." (1994:190)

Kutipan ini menunjukkan, wartawan sesungguhnya merupakan seorang intelektual. Dengan posisi ini wajar saja kalau dia berusaha meningkatkan intelektualitas khalayak. Namun, kondisi ekosistem media menyebabkan dia tidak bisa mewujudkan idealismenya secara utuh. Dia selalu gamang meniti idealismenya. Kegamangan itu tidak pernah berhenti, mulai dari orde baru, terus ke orde reformasi hingga ke zaman digitalisasi seperti sekarang ini.

Biar begitu, wartawan tetap tidak boleh meninggalkan posisinya sebagai intelektual. Dia harus tetap bertekad tidak akan pernah menjalani profesinya secara "aksi-reaksi"dan sekadar memenuhi aturan administratif tanpa proses refleksi yang serius, seperti yang dialamatkan Mohamad Sobary kepada wartawan yang tidak idealis. 
Dari tekad ini lah terpantul sikap yang kuat untuk memperjuangkan idealisme wartawan. Dari tekad ini pula muncul harapan untuk melihat pengembangan wacana cerdas yang dibutuhkan untuk meningkatkan intelektualitas khalayak. Kalau harapan ini kelak terwujud, kata Hermin Indah Wahyuni (2020:35), dalam buku Keriuhan Komunikasi, lahirlah wartawan yang berdedikasi melahirkan wacana-wacana yang rasional dalam masyarakat.

Wacana-wacana rasional ini sangat dibutuhkan dalam berbagai tema berita, termasuk berita pelanggaran hak asasi manusia (HAM). Dengan membayangkan wacana seperti ini, Ana Nadhya Abrar dalam tulisannya berjudul West Papua Journalists Today: An Alternative Human Rights Perspective from Indonesia mengusulkan lima ciri-ciri berita pelanggaran HAM yang ideal, meliputi:

1. Menawarkan refleksi kritis tentang pengalaman dan kebutuhan pada korban dan pelaku pelanggaran hak asasi manusia (fisik, budaya, dan struktural).

2. Memberikan solusi, bukan kemenangan.

3. Menyampaikan kebenaran, bukan propaganda.

4. Memprioritaskan masyarakat, bukan elit.

5. Meraih menang-menang, bukan menang kalah (2020:129).*** 


\section{Referensi}

Abrar, A. N. (2005). Penulisan Berita. Yogyakarta: Universitas Atma Jaya Yogyakarta.

Abrar, A. N. (2020). West Papuan journalists today: An alternative human rights perspective from Indonesia. Pacific Journalism Review, 26(1), 123-139. https://doi.org/10.24135/pjr.v26i1.1075

Abrar, A. N. (2021). Susila Wartawan Muslim. Yogyakarta: UGM Press.

Brown, S. (2017). Prime Time. PT. Gramedia Pustaka Utama.

Kompas.com. (21 Januari 2013). Merasa Diperlakukan Tak Adil, Mantan Jurnalis Mengadu ke DPR. Retrieved from https://nasional.kompas.com/read/2013/01/21/11291594/ Nasional,

Kristiawan, R. (2011). Jerat Negara dan Pasar dalam Ruang Publik. Prisma, 30(1), 44-57. Retrieved from https://prismajurnal.com/issues.php?id=c2ec5136-56bf-11e3-a6cc$429 \mathrm{e} 1 \mathrm{~b} 0 \mathrm{bc} 2 \mathrm{fa} \& \mathrm{bid}=2 \mathrm{a} 846 \mathrm{~b} 1 \mathrm{a}-56 \mathrm{~b} 8-11 \mathrm{e} 3-\mathrm{a} 6 \mathrm{cc}-429 \mathrm{e} 1 \mathrm{~b} 0 \mathrm{bc} 2 \mathrm{fa}$

McChesney, R. W. (2000). Rich Media, Poor Democracy: Communication Politics in Dubious Times: Communication Politics in Dubious Times. New York: The News Press.

Safrizal, C. R. (2021). Pertarungan Fungsi Sosial dan Fungsi Media (Studi Kasus Reporter Media Online Tribunjogja.com Tahun 2019-2020).

Sihotang, K. (2018). Filsafat Manusia: Jendela Mengungkap Humanisme. Kanisius.

Siregar, A. (1985). Catatan Pendahuluan Dari Penyunting Perjalanan Panjang Mencari Corak. In A. Siregar (Ed.), Profesi Wartawan di Mata Saya (pp. 111). Yogyakarta: LP3Y.

Siregar, A. (2003). Politik Editorial Media Indonesia: Analisis Tajuk Recana 19982001. Jakarta: LP3ES.

Sobary, M. (1994). Moralitas Kaum Pinggiran (E. Supriyanto, Ed.). Bandung: Mizan.

Sudibyo, A. (2019). Jagat Digital: Pembebasan dan Penguasaan. Jakarta: Kepustakaan Populer Gramedia.

Wahyuni, H. I. (2020). Keriuhan Komunikasi. Jakarta: Yayasan Obor Indonesia.

\section{Profil Penulis}


Ana Nadhya Abrar lahir di Bukittinggi, 20 Februari 1959. Dia mulai mengenal jurnalisme tahun 1982, saat mengikuti Kursus Jurnalistik Tingkat Dasar PWI Bukittinggi. Kemudian dia berkuliah di Jurusan Publisistik UGM. Tahun 1994 dia memperoleh gelar M.E.S. dalam jurnalisme lingkungan hidup dari York University, Toronto, Kanada. Tahun 2010 dia memperoleh gelar Ph.D dalam jurnalisme dari Universiti Malaya, Kuala Lumpur, Malaysia. Dia tinggal di Yogyakarta sejak 1982 dan menekuni 3 MJ: Mengajar Jurnalisme, Menelaah Jurnalisme, dan Mempraktikkan Jurnalisme. Yang terakhir ini dia lakukan dengan menulis biografi, profil lembaga, obituari dan mozaik profil. Dia sudah menulis lima biografi, satu obituari, tiga mozaik profil, dan empat profil lembaga. 